\title{
Pyropia acanthophora var. brasiliensis E. C. Oliveira and Coll (Rhodophyta: Bangiales) cultivated in seawater under laboratory conditions favors the production of economically important secondary metabolites
}

\section{Débora Tomazi Pereira ${ }^{1}, *$, Elisa Poltronieri Filipin ${ }^{1}$, Fernanda Ramlov $^{2}$, Marcelo Maraschin ${ }^{2}$, Zenilda Laurita Bouzon ${ }^{1}$ and Carmen Simioni ${ }^{1}$}

${ }^{1}$ Plant Cell Biology Laboratory. Department of Cell Biology. Embryology and
Genetics. Federal University of Santa Catarina. Caixa Postal 476. Florianópolis-SC,
Brazil (CEP 88049-900). *Email: de.tomazi@gmail.com.
${ }^{2}$ Plant Morphogenesis and Biochemistry Laboratory. Federal University of Santa
Catarina. Caixa Postal 476. Florianópolis-SC, Brazil (CEP 88049-900).

Abstract. Pyropia represents most domesticated seaweed in the world. Therefore, we aimed to determine if cultivation of the red macroalga Pyropia acanthophora E. C. Oliveira and Coll (Rhodophyta: Bangiales) under laboratory conditions would affect the presence and concentration of secondary metabolites. To accomplish this, experiments were performed with ambient sample and acclimated sample (laboratory conditions). The conditions of the culture room were as follows: $24^{\circ} \mathrm{C}$, salinity of $35 \%$, constant aeration, irradiance of $80 \mu \mathrm{mol}$.photons. $\mathrm{m}^{-2} \cdot \mathrm{s}^{-1}$ and photoperiod of $12 \mathrm{~h}$, for 7 days. Ambient sample showed lower concentrations of allophycocyanin and phycoerythrin when compared to the acclimated sample, but phycocyanin concentration was higher in the ambient sample. Carotenoids showed higher concentrations in the acclimated sample when compared to the ambient sample. Total phenolics were insignificant, while total flavonoids were higher in the ambient sample. No pattern in the production of these secondary metabolites could be identified. On the other hand, the acclimated samples showed a greater inhibition of the free radical DPPH, indicating a higher antioxidant activity. Acclimatization under laboratory conditions, in which P. acanthophora is submerged in seawater, favors the production of economically important secondary metabolites as a result of submersion stress and changes in cultivation patterns, such as irradiance and photoperiod.

Keywords: Carotenoids; Flavonoids; Phenolics; Phycobiliproteins.
Received

March 16, 2018

Accepted

April 22, 2018

Released

April 30, 2018

Full Text Article

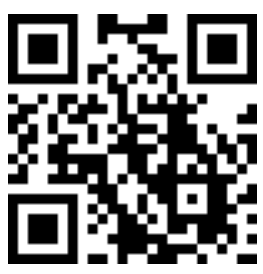

ORCID

D) $0000-0002-2330-8812$

Débora Tomazi

Pereira

(D) $0000-0002-5252-0812$

Elisa Poltronieri

Filipin

(D) 0000-0001-7925-3980

Fernanda Ramlov 


\section{Introduction}

Pyropia is the most domesticated seaweed in the world (Schweikert et al., 2011). It is known as Nori, the seaweed of sushi, and used in food all over the world (Zhang et al., 2003; Zhou et al., 2012). In the environment, it is located in the interdial zone where it is submerged during high tide and exposed at low tide (Chan et al., 2012).

The main secondary antioxidant metabolites present in red macroalgae are carotenoids, phenolics and flavonoids (Aple and Hirt, 2004; Ganesan et al., 2008; Borges et al., 2011). In addition, phycobiliproteins, photosynthetic pigments, also have an antioxidant function (Chamorro et al., 2002; Romay et al., 2003), as they absorb radiation (Munier et al., 2014), acting as a protector of chlorophyll $a$, the principal pigment related to photosynthesis.

Phycobiliproteins,

allophycocyanin (APC), phycocyanin (PC) and phycoerythrin (PE), are organized into a complex antenna on the chloroplast thylakoid membrane where APC is at the center above chlorophyll, followed by PC and PE at the terminal (Parmar et al., 2013).

Carotenoids have two cellular functions. The first is the pigment function, acting to absorb light for photosynthesis (Christaki et al., 2012), and the second is photoprotection, eliminating reactive oxygen species (ROS) (Uenojo et al., 2007; Ramlov, 2010). Carotenoids are used as food additives in the form of dyes and vitamins and also in the cosmetics and pharmaceutical industries because of

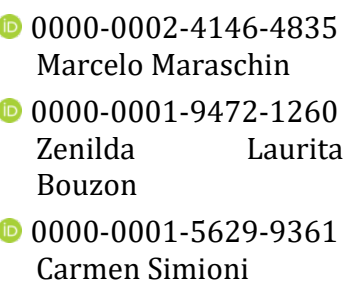

their protection against free radicals (Fré et al., 2014).

Flavonoids are the largest class within phenolics, and they act in defense against solar radiation, especially ultraviolet radiation, and against aggression by pathogens, predators or parasites (Dai and Mumper, 2010). Phenols and flavonoids have antioxidant properties because they are reducing agents, hydrogen donors, and singlet oxygen suppressors (Rice-Evans et al., 1995; Papp et al., 2004). In addition, they also act as a metal chelator (Rice-Evans et al., 1995; Papp et al., 2004). Flavonoids are compounds that can be used for their antimicrobial (Seenivasan et al., 2012) and antitumor activities (Lavakumar et al., 2012). Phenolic compounds provide antiproliferation (Murugan et al., 2014) and anti-inflammatory activity (Guimarães, 2014).

This work aims to analyze the presence and concentration of secondary metabolites of the red macroalga Pyropia acanthophora var. brasiliensis E.C. Oliveira and Coll (Rhodophyta: Bangiales) cultivated under laboratory conditions to determine any resultant changes in the quantity of these metabolites.

\section{Materials and methods}

\section{biological material}

The gametophytes of P. acanthophora var. brasiliensis were collected in the upper portion of the interdial zone of the rocky shore of Sambaqui Beach, Florianópolis, Santa Catarina State, Brazil, in August and September 2015. The environmental 
conditions of the water were $19^{\circ} \mathrm{C}$, salinity 35\%o, and photoperiod of $10 \mathrm{~h}$ clear and $14 \mathrm{~h}$ dark. Algal thalli were transported to the Laboratory of Plant Cell Biology, which is located at the Federal University of Santa Catarina (Florianópolis), in plastic containers containing seawater. In the laboratory, thalli were washed with filtered and sterilized seawater and screened for the removal of epiphytes.

Some healthy portions were stored in liquid nitrogen for extraction of the secondary metabolites; these were denominated ambient samples. Other healthy portions were cultivated in the laboratory $(n=4)$ with sterilized seawater from the collection site, plus von Stosch's medium (100\%, Edwards 1972), for 7 days under controlled conditions; these were denominated acclimated samples.

The conditions of the culture room were as follows: temperature of $24{ }^{\circ} \mathrm{C} \pm 2{ }^{\circ} \mathrm{C}$, salinity of $35 \%$, constant aeration, irradiance of $80 \pm$ $10 \mu$ mol.photons. $\mathrm{m}^{-2} \cdot \mathrm{s}^{-1} \quad$ (florescent lamps, Philips C-5 Super 8416 W/840, Brazil), and photoperiod of $12 \mathrm{~h}$. At the beginning of the fourth day of experiment, seawater was changed.

\section{Phycobiliproteins}

The extraction of phycobiliproteins was accomplished through the grinding of $0.5 \mathrm{~g}$ (fresh mass) in liquid nitrogen. The macerate was suspended in $3 \mathrm{~mL}$ of $50 \mathrm{mM}$ phosphate buffer, pH 5.5 and $4{ }^{\circ} \mathrm{C}$. The solution was centrifuged for $20 \mathrm{~min}$ $\left(4,000 \mathrm{rpm}\right.$ at $\left.4{ }^{\circ} \mathrm{C}\right)$, and the supernatant was removed and kept in the dark until reading at 498, 615 and $651 \mathrm{~nm}$ in a microplate reader (Infinite M200, Tecan Multileiter). The formulas described by Kursar et al. (1983) were used. The analyses were performed with $n=4$, and the results were expressed in $\mu \mathrm{g}$ of pigments per $\mathrm{g}$ of dry mass.

\section{Extraction and dosing of total carotenoids}

Samples of $0.5 \mathrm{~g}$ (fresh mass)

were ground in liquid nitrogen, macerated in $10 \mathrm{~mL}$ of pure methanol, and kept at rest $(1 \mathrm{~h})$ in a darkroom. Then, the reading was carried out at $450 \mathrm{~nm}$ in a microplate reader (Aman et al., 2005). The quantification of the total carotenoids was made from the standard curve of $\beta$-carotene (6.25 to $50 \mu \mathrm{g} . \mathrm{mL}^{-1}$ $\left.\mathrm{r}^{2}=0.99 ; \mathrm{y}=1.624 \mathrm{x}\right)$. The analyses were performed with $n=4$, and the results were expressed in $\mu$ g per $g$ of dry mass.

\section{phenolics}

\section{Extraction and dosing of total}

Samples of $0.5 \mathrm{~g}$ (fresh mass) were ground in liquid nitrogen, macerated in $10 \mathrm{~mL}$ of $80 \%$ methanol, and kept at rest $(1 \mathrm{~h})$ in a darkroom. The analysis was performed using the FolinCiocalteau spectrophotometric method based on Waterman and Mole (1994). $50 \mu \mathrm{L}$ aliquots from the supernatant of the extracts were added to a concentrated solution of $180 \mu \mathrm{L}$ of distilled water, $10 \mu \mathrm{L}$ of the FolinCiocalteau (Vetec) reagent and $30 \mu \mathrm{L}$ of $20 \%$ sodium carbonate $\left(\mathrm{Na}_{2} \mathrm{CO}_{3}, \mathrm{w} / \mathrm{v}\right)$ and incubated for $1 \mathrm{~h}$ at room temperature. Thereafter, the reading was carried out at $750 \mathrm{~nm}$ on a microplate reader. The quantification of the total phenolic compounds was done from the standard curve of gallic acid (1 to $50 \mu \mathrm{g} . \mathrm{mL}^{-1}-\mathrm{r}^{2}=0.99 ; \mathrm{y}=0.0004 \mathrm{x}$ ). The analyses were performed with $n=4$, and the results were expressed in $\mu$ g of gallic acid per $g$ of dry mass.

\section{flavonoids}

\section{Extraction and dosing of total}

The extract was prepared as described above for total phenolics. An aliquot of $0.5 \mathrm{~mL}$ of each extract was used to determine the total flavonoid content in the presence of $0.5 \mathrm{~mL}$ of aluminum chloride solution $2 \%$ in 
methanol) and $2.5 \mathrm{~mL}$ of ethanol, according to Zacarias et al. (2007), with modifications. After standing for $1 \mathrm{~h}$, the reading was carried out at $420 \mathrm{~nm}$ on a microplate reader. The quantification of flavonoids was made from the standard quercetin curve (1 to $20 \mu \mathrm{g} \cdot \mathrm{mL}^{-1}$ $\left.r^{2}=0.99 ; y=0.009 x\right)$. The analyses were performed with $n=4$, and the results were expressed in $\mu \mathrm{g}$ of quercetin per $\mathrm{g}$ of dry mass.

\section{Inhibition of Radical DPPH (1,1-diphenyl-2-picrylhydrazyl) \\ An aliquot of $250 \mu \mathrm{L}$ of DPPH} (Sigma, $0.1 \mathrm{mM}$ in $80 \%$ methanol) methanolic solution was added to $50 \mu \mathrm{L}$ of the extract prepared as described above for total phenolics. The decrease in absorbance at $530 \mathrm{~nm}$ was measured on a microplate reader after $30 \mathrm{~min}$ incubation of the sample, according to Kim et al. (2002). The analyses were performed with $n=4$, and the results were expressed as porcentage of free radical sequestration DPPH.

\section{Statistical analysis}

The data were submitted to the $t$-test using Statistica v. 10.0 software, considering the significance of the test at $5 \%$.

\section{Results and discussion}

Secondary metabolites are compounds that have no direct function on the growth and development of organisms, but they do play a key role in their interaction with the environment (Verpoorte, 2000). Most secondary metabolites acting as antioxidants and scavengers of free radicals calculated as porcentage inhibition were verified in the acclimated samples. In nature, P. acanthophora var. brasiliensis occurs in the interdial zone and is submerged only during high tides. However, under laboratory conditions, the alga is commonly submerged $24 \mathrm{~h}$ a day, which can be stressful, resulting in an imbalance in metabolite production and causing, in turn, the formation of ROS such that the production of secondary metabolites serves to repair damage caused by stress.

The thalli of ambient samples is greenish and about $16 \mathrm{~cm}$ wide (Figure 1a), while the acclimated thalli is fragmented and presents a brownish coloration (Figure 1b), indicating that the stem is forming fertile cells, a possible form of dispersion of the species in an unfavorable environment, such as submersion.

\section{Ambiente}

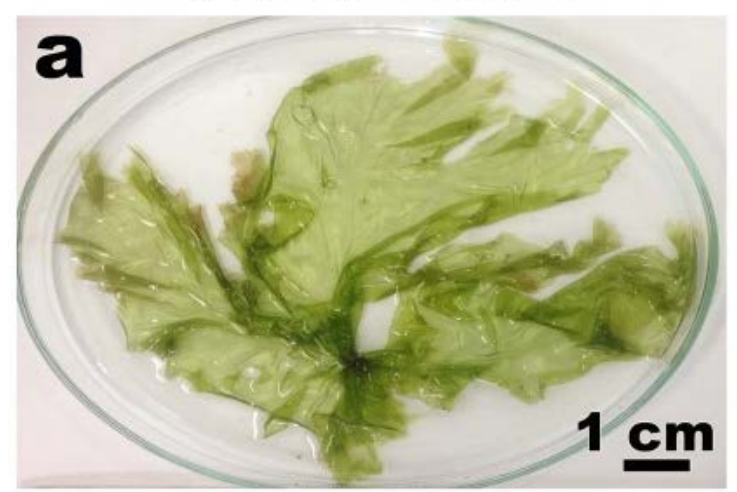

\section{Laboratório}

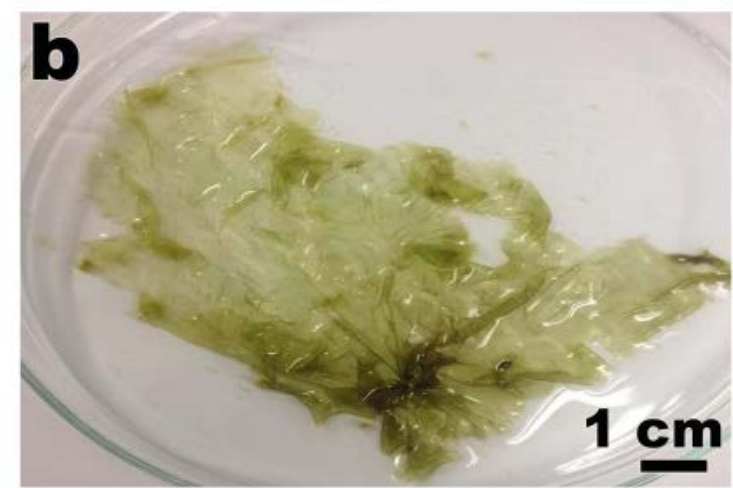

Figure 1. External morphology of the thalli of the red macroalga Pyropia acanthophora var. brasiliensis from $\mathbf{a}$. ambient and $\mathbf{b}$. acclimated in laboratory. 
a
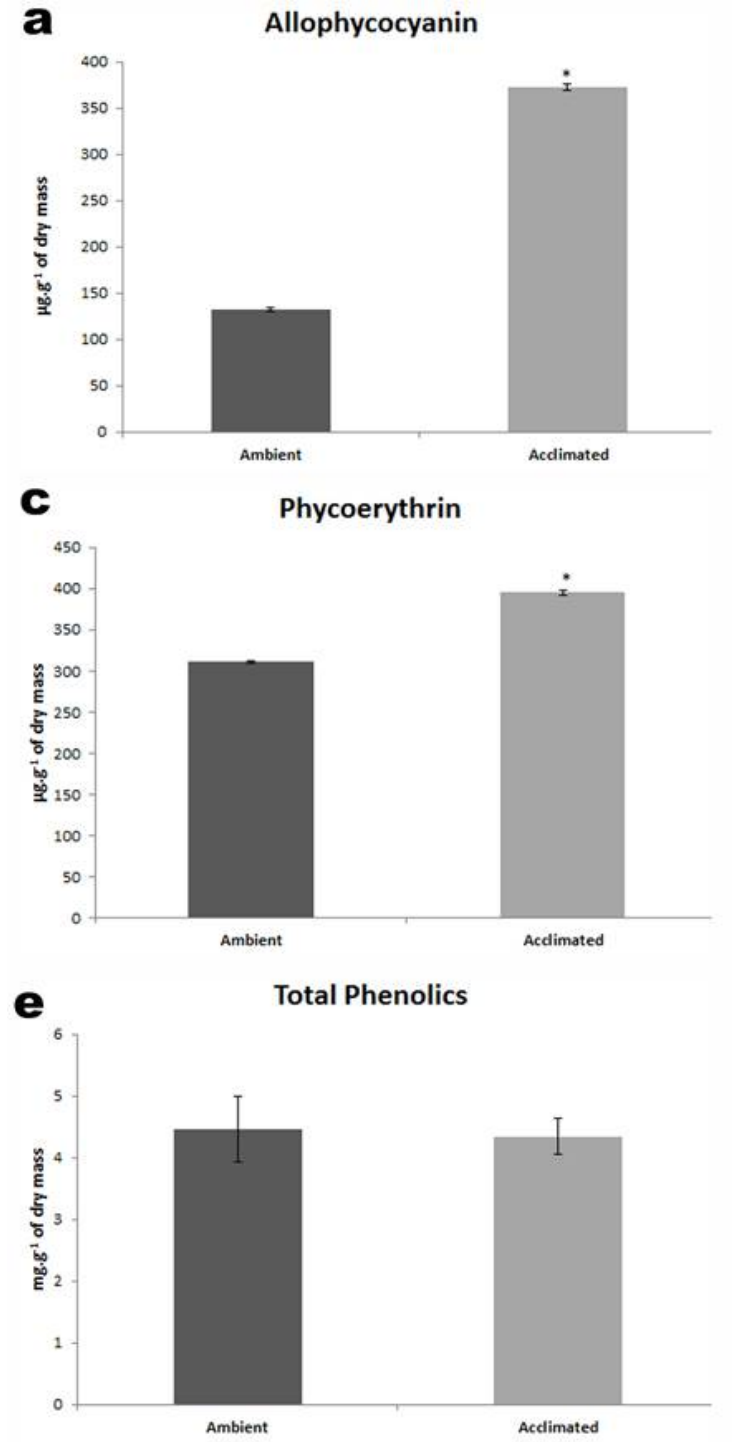
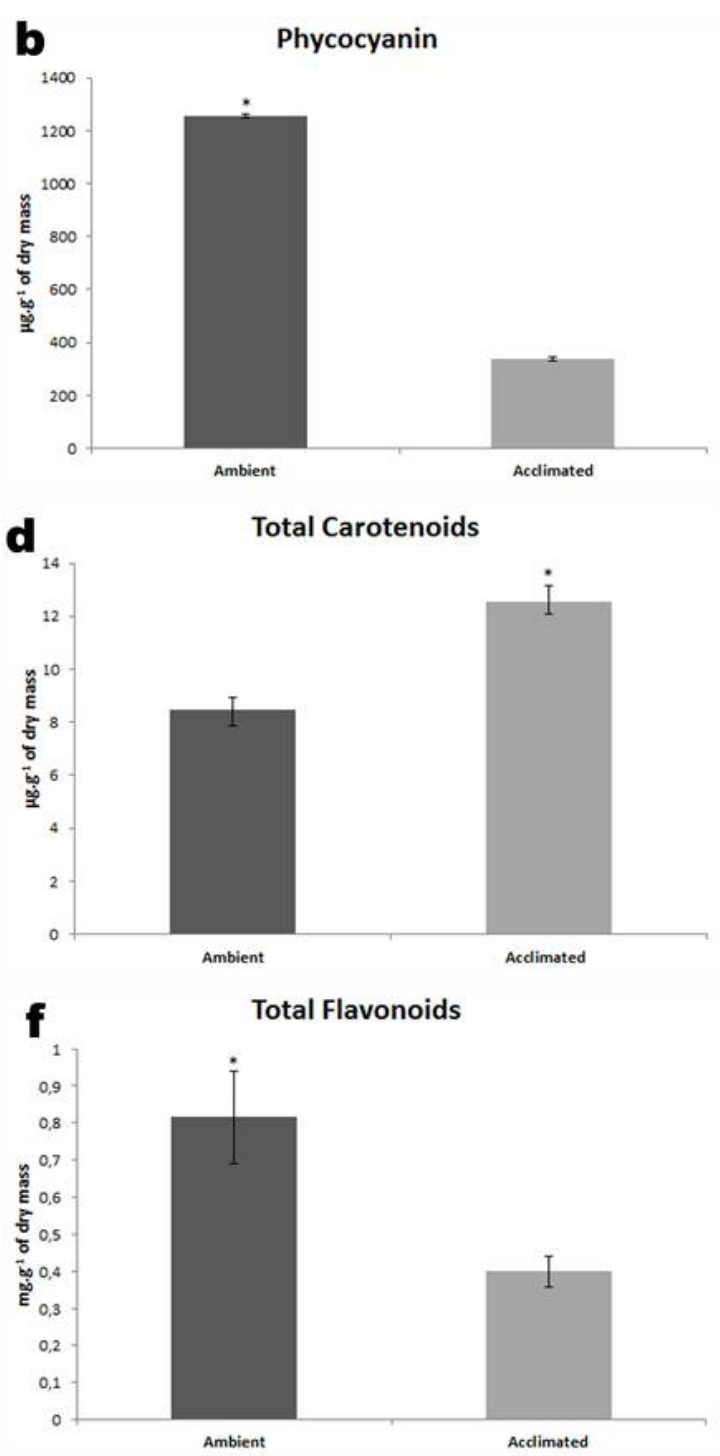

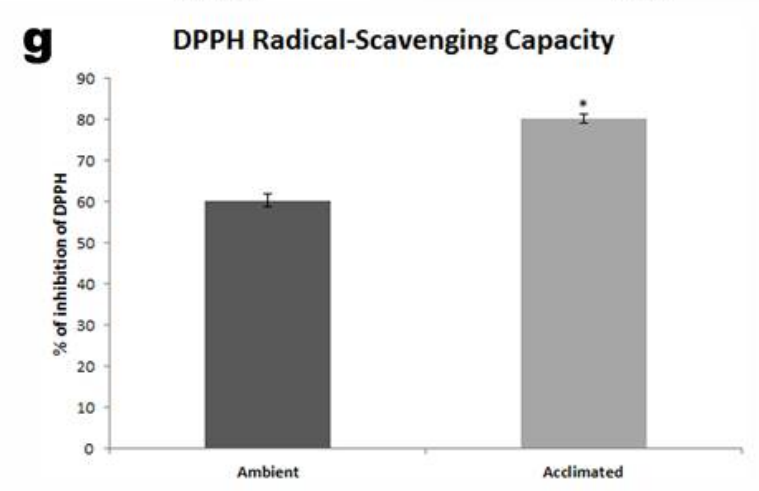

Figure 2. Content of a. allophycocyanin ( $\mu \mathrm{g} \cdot \mathrm{g}^{-1}$ of dry mass), b. phycocyanin ( $\mu \mathrm{g} \cdot \mathrm{g}^{-1}$ of dry mass), c. phycoerythrin ( $\mu \mathrm{g} \cdot \mathrm{g}^{-1}$ of dry mass), d. carotenoids ( $\mu \mathrm{g} \cdot \mathrm{g}^{-1}$ of dry mass), e. phenolic (mg.g ${ }^{-1}$ of dry mass), f. flavonoid (mg.g-1 of dry mass), g. inhibition of DPPH (\%) of ambient and acclimated samples of Pyropia acanthophora var. brasiliensis $(\mathrm{n}=4$, mean $\pm \mathrm{SD})$. Asterisks indicate significant differences according to $t$ test $(\mathrm{p} \leq 0.05)$. 
The concentration of phycobiliproteins underwent changes after acclimatization. The ambient sample showed significantly lower concentrations of allophycocyanin (APC) $\left[\mathrm{t}_{(4)}=56.56, \mathrm{p}<0.0001\right.$ ] (Figure 2a) and phycoerythrin (PE) $\quad\left[\mathrm{t}_{(4)}=-64.32\right.$, $\mathrm{p}<0.0001$ ] when compared to the acclimated sample (Figure 2c). On the other hand, the concentration of phycocyanin (PC) $\quad\left[\mathrm{t}_{(4)}=180.00\right.$, $\mathrm{p}<0.0001$ ] was higher in the ambient sample compared to the acclimated sample (Figure 2b). It is suggested that the highest concentrations of phycobiliproteins occurred in acclimated samples from exposure to direct light for $12 \mathrm{~h}$, a greater exposure than that found in the field of only $10 \mathrm{~h}$. The increase of phycobiliproteins was also observed in Aglaothamnion uruguayense (W. R. Taylor) N. E. Aponte, D. L. Ballantine and J. N. Norris exposed to ultraviolet-B radiation (Ouriques et al., 2017) and Gracilaria tenuistipitata C. F. Chang and B. M. Xia exposed to hypoxic and hypersaline conditions (Israel et al., 1999). In addition to the function of accessory pigments and photoprotection of chlorophyll $a$, the phycobiliproteins can act as oxidation-reduction (REDOX) components in order to eliminate ROS (Kumar et al., 2010; Rodriguez-Sanchez et al., 2012).

Carotenoids, phenolics and flavonoids are the main antioxidant agents in red algae (Aple and Hirt, 2004; Ganesan et al., 2008; Borges et al., 2011) under stress conditions. The concentration of total carotenoids was higher in the acclimated sample $\left[\mathrm{t}_{(4)}=-9.26, \mathrm{p}<0.001\right]$ when compared to the ambient sample (Figure 2d). The total phenolic concentration was not significantly affected by acclimation compared to the ambient sample $\left[\mathrm{t}_{(4)}=5.21, \quad \mathrm{p}<0.01\right] \quad$ (Figure 2e). However, the concentration of total flavonoids was higher in the ambient sample [t (4) = 5.21, $p<0.01]$ (Figure 2f). No pattern in the production of these secondary metabolites was observed. On the other hand, the acclimated samples showed a greater inhibition of the free radical DPPH $\left[\mathrm{t}_{(4)}=-15.04, \mathrm{p}<0.001\right]$ (Figure 2g), indicating a higher antioxidant activity in these samples and suggesting, in turn, that the acclimatized condition becomes a stress factor that accounts for the high concentration of carotenoids in the acclimated sample. Meanwhile, the lower concentrations of carotenoids compared to phycobiliproteins shows that carotenoids act to protect the photosynthetic apparatus of algae (Ramlov et al., 2011).

Many of these compounds have biological activity of interest to the pharmaceutical and food industries. It follows that the isolation and chemical characterization of secondary metabolities produced in greater quantities by acclimated algae submerged $24 \mathrm{~h}$ a day would have economic significance.

\section{Conclusion}

P. acanthophora var. brasiliensis cultivated in seawater under laboratory conditions favors the production of economically important secondary metabolites, such as phycobiliproteins and carotenoids, owing to submersion stress and changes in cultivation patterns, such as irradiance and photoperiod.

\section{Acknowledgments}

The authors acknowledge the Conselho Nacional de Desenvolvimento Científico e Tecnológico (CNPq, Brazil) for the financial support. Zenilda $\mathrm{L}$. Bouzon is a CNPq fellow. This study is part of the part of the Ph.D. thesis of the first author.

\section{Conflict of interests}

The authors declare that there are no conflicts of interest. 


\section{References}

Aman, R.; Carle, R.; Beifuss, U.; Schieber, A. Isolation of carotenoids from plant materials and dietary supplements by high-speed counter-current chromatography. Journal of Chromatography A, v. 1074 , no. $1 / 2$, p. $99-105,2005$. https://doi.org/10.1016/ j.chroma.2005.03.055

Aple, K.; Hirt, H. Reactive oxygen species: metabolism, oxidative stress, and signal transduction. Annual Review of Plant Biology, v. 55, p. 373-399, 2004. https://doi.org/10.1146/annurev.arplant.55. 031903.141701

Borges, J. C.; Silva, M. R.; Esper, C. R.; Franceschini, P. H. Membrana plasmática de espermatozoides bovinos: efeito de metabólitos do oxigênio, antioxidantes e criopreservação. Revista Brasileira de Reprodução Animal, v. 35, no. 3, p. 303-314, 2011. Available from: <http://cbra.org.br/ pages/publicacoes/rbra/v35n3/pag303314.pdf>. Accessed on: Feb. 23, 2018.

Chamorro, G.; Salazar, M.; Araújo, K. G. L.; Santos, C. P.; Ceballos, G.; Castillo, L. F. Actualización en la farmacología de Spirulina (Arthrospira), un alimento no convencional. Archivos Latinoamericanos de Nutrición, v. 52, no. 3, p. 232-240, 2002. Available from: <http://www.scielo.org.ve/scielo.php?script =sci_arttext\&pid=S0004-0622200200030 0002>. Accessed on: Feb. 23, 2018.

Chan, C. X.; Zäuner, S.; Wheeler, G.; Grossman, A. R.; Prochnik, S. E.; Blouin, N. A.; Zhuang, Y.; Benning, C.; Berg, G. M.; Yarish, C.; Eriksen, R. L.; Klein, A. S.; Lin, S.; Levine, I.; Brawley, S. H.; Bhattacharya, D. Analysis of Porphyra membrane transporters demonstrates gene transfer among photosynthetic eukaryotes and numerous sodium-coupled transport systems. Plant Physiology, v. 158, p. 2001-2012, 2012. https://doi.org/ 10.1104/pp.112.193896

Christaki, E.; Bonos, E.; Giannenasa, I.; FlorouPaneria, P. Functional properties of carotenoids originating from algae. Journal of the Science of Food and Agriculture, v. 93 , no. 1, p. 5-11, 2012. https://doi.org/ $10.1002 /$ jsfa.5902

Dai, J.; Mumper, R.J. Plant phenolics: Extraction, analysis and their antioxidant and anticancer properties. Molecules, v. 15, no. 10 , p. 7313-7352, 2010. https://doi.org/ 10.3390/molecules15107313
Edwards, P. Cultured red alga to measure pollution. Marine Pollution Bulletin, v. 3, p. 184-188, 1972.

Fré, N. C.; Rech, R.; Marcílio, N. Influência da luminosidade e concentração salina na produção de lipídios e carotenoides pela microalga Dunaliella tertiolecta em fotobiorreator airlift. Proceeding of the X Congresso Brasileiro de Engenharia Química, 2014. Available from: <http://pdf.blucher. com.br.s3-sa-east-1.amazonaws.com/ chemicalengineeringproceedings/cobeq2014 /1171-20672-176720.pdf>. Accessed on: Feb. 23, 2018.

Ganesan, P.; Kumar, C.S.; Bhaskar, N. Antioxidant properties of methanol extract and its solvent fractions obtained from selected Indian red seaweeds. Bioresource Technology, v. 99, no. 8, p. 2717-2723, 2008. https://doi.org/10.1016/j.biortech.2007.07. 005

Guimarães, D. H.; Boscolo, T. Determinação das propriedades reológicas da polpa de framboesa amarela (Rubus imperialis) e processamento da geleia a partir da mesma. Revista Ciências Exatas e Naturais, v. 15, no. 3, p. 275-287, 2014. Available from: <https://revistas.unicentro.br/index.php/RE CEN/article/view/2568/2311>. Accessed on: Feb. 23, 2018.

Israel, A.; Martinez-Goss, M.; Friedlander, M. Effect of salinity and $\mathrm{pH}$ on growth and agar yield of Gracilaria tenuistipitata var. liui in laboratory and outdoor cultivation. Journal of Applied Phycology, v. 11, no. 6, p. 543-549, 1999. https://doi.org/10.1023/ A:1008141906299

Kim, Y. K.; Guo, Q.; Packer, L. Free radical scavenging activity of red ginseng aqueous extracts. Toxicology, v.172, no. 2, p. 149-156, 2002. https://doi.org/10.1016/ S0300-483X(01)00585-6

Kumar, M.; Kumari, P.; Gupta, V.; Reddy, C. R. K.; Jha, B. Biochemical responses of red alga Gracilaria corticata (Gracilariales, Rhodophyta) to salinity induced oxidative stress. Journal of Experimental Marine Biology and Ecology, v. 391, no. 1/2, p. 27-34, 2010. https://doi.org/10.1016/ j.jembe.2010.06.001

Kursar, T. A.; Alberte, R. S. Photosynthetic unit organization in a red alga. Plant Physiology, v. 72, no. 2, p. 409-414, 1983. https://doi.org/10.1104/pp.72.2.409 
Lavakumar, $\quad$ V.; $\quad$ Ahamed, $\quad$ K. F. H.; Ravichandran, V. Anticancer and antioxidant effect of Acanthophora spicifera against EAC induced carcinoma in mice. Journal of Pharmacy Research, v. 5, no. 3, p.1503-1507, 2012. Available from: <http://jprsolutions.info/newfiles/journalfile-56adabbe863f84.64946915.pdf>. Accessed on: Feb. 23, 2018.

Munier, M.; Jubeau, S.; Wijaya, A.; Morançais, M.; Dumaya, J.; Marchal, L.; Jaouen, P.; Fleurence, J. Physicochemical factors affecting the stability of two pigments: R-phycoerythrin of Grateloupia turuturu and B-phycoerythrin of Porphyridium cruentum. Food Chemistry, v. 150, p. 400-407, 2014. https://doi.org/10.1016/j.foodchem.2013.10 .113

Murugan, K.; Iyer, V. V. Antioxidant and antiproliferative activities of extracts of selected red and brown seaweeds from the Mandapam Coast of Tamil Nadu. Journal of Food Biochemistry, v. 38, p. 92-101, 2014. https://doi.org/10.1111/jfbc.12029

Ouriques, L. C.; Pereira, D. T.; Simioni, C.; Ramlov, F.; Maraschin, M.; Bouzon, Z. L.; Schmidt, E. C. Physiological, morphological and ultrastructural responses to exposure to ultraviolet radiation in the red alga Aglaothamnion uruguayense (W. R. Taylor). Brazilian Jounal of Botany, v. 40, no. 3, p. 783-791, 2017. https://doi.org/10.1007/ s40415-017-0372-5

Papp, I.; Apáti, P.; Andrasek, V.; Blázovics, A.; Balázs, A.; Kursinszki, L.; Kite, G. C.; Houghton, P. J.; Kéry, A. LC-MS analysis of antioxidant plant phenoloids. Chromatographia, v. 60, suppl. 1, p. S93S100, 2004. https://doi.org/10.1365/ s10337-004-0348-z

Parmar, A.; Singh, N. K.; Dhoke, R.; Madamwar, D. Influence of light on phycobiliprotein production in three marine cyanobacterial cultures. Acta Physiologie Plantarum, v. 35, no. 6, p. 1817-1826, 2013. https://doi.org/10.1007/s11738-013-1219-8

Ramlov, F. Variação sazonal dos carotenóides e compostos fenólicos e estudos fisiológicos em diferentes estádios reprodutivos de Gracilaria domingensis (Kütz.) Sonder ex Dickie (Gracilariales, Rhodophyta). São Paulo: Instituto de Botânica, 2010 (Thesis of doctorat).
Ramlov, F.; Souza, J. M. C.; Faria, A. V. F.; Maraschin, M.; Horta, P. A.; Yokoya, N.S. Growth and accumulation of carotenoids and nitrogen compounds in Gracilaria domingensis (Kutz.) Sonder ex Dickie (Gracilariales, Rhodophyta) cultured under different irradiance and nutrient levels. Revista Brasileira de Farmacognosia, v. 21, n. 2, p. 255-261, 2011. https://doi.org/ 10.1590/S0102-695X2011005000081

Rice-Evans, C.; Miller, N. J.; Bolwell, P. G.; Bramley, P. M.; Pridham, J. B. The relative antioxidant activities of plant-derived polyphenolic flavonoids. Free Radical Research, v. 22, no. 4, p. 375-383, 1995. https://doi.org/10.3109/107157695091456 49

Rodríguez-Sánchez, R.; Ortiz-Butrón, R.; BlasValdivia, V.; Hernández-García, A.; CanoEuropa, E. Phycobiliproteins or C-phycocyanin of Arthrospira (Spirulina) maxima protect against $\mathrm{HgCl}_{2}$-caused oxidative stress and renal damage. Food Chemistry, v. 135, no. 4, p. 2359-2365, 2012. https://doi.org/10.1016/j.foodchem.2012.07 .063

Romay, Ch.; González, R.; Ledón, N.; Remirez, D.; Rimbau V. C-phycocyanin: a biliprotein with antioxidant, anti-inflammatory and neuroprotective effects. Current Protein \& Peptide Science, v. 4, no. 3, p. 207-216, 2003. https://doi.org/10.2174/1389203033 487216

Schweikert, K.; Sutherland, J. E. S.; Hurd, C. L.; Burritt, D. J. UV-B radiation induces changes in polyamine metabolism in the red seaweed Porphyra cinnamomea. Plant Growth Regulation, v. 65, p. 389-399, 2011. https://doi.org/10.1007/s10725-011-9614-x

Seenivasan, R.; Rekha, M.; Indu, H.; Geetha, S. Antibacterial activity and phytochemical analysis of selected seaweeds from Mandapam Coast, India. Journal of Applied Pharmaceutical Science, v. 2, p. 159-169, 2012. https://doi.org/10.7324/JAPS.2012. 21030

Uenojo, M.; Maróstica, M. R.; Pastore, G. M. Carotenóides: propriedades, aplicações e biotransformação para formação de compostos de aroma. Química Nova, v. 30, p. 616-622, 2007. https://doi.org/10.1590/ S0100-40422007000300022

Verpoorte, R.; van der Heijden, R.; Memelink, J. Engineering the plant cell factory for secondary metabolite production. 
Transgenic Research, v. 9, no. 4/5, p. 323343, 2000. https://doi.org/10.1023/A:10089 66404981

Waterman, P. G.; Mole, S. Analysis of phenolic plant metabolites. Oxford: Blackwell Scientific Publications, 1994.

Zacarias, A. A.; Moresco, H. H.; Horst, H.; Brighente, I. M. C.; Marques, M. C. A.; Pizzollati, M. G. Determinação do teor de fenólicos e flavonoides no extrato e frações de Tabebuia heptaphylla. Proceeding of the 30 a Reunião Anual da Sociedade Brasileira de Química, 2007. Available from: <https://sec.sbq.org.br/cdrom/30ra/ resumos/T1086-1.pdf>. Accessed on: Feb. 22, 2018.

Zhang, Q.; Yu, P.; Li, Z.; Zhang, H.; Xu, Z.; Li, P. Antioxidant activities of sulfated polysaccharide fractions from Porphyra haitanesis. Journal of Applied Phycology, v. 15, no. $4, \quad$ p. $305-310, \quad 2003$. https://doi.org/10.1023/A:1025137728525

Zhou, C.; Yu, X.; Zhang, Y.; He, R.; Ma, H. Ultrasonic degradation, purification and analysis of structure and antioxidant activity of polysaccharide from Porphyra yezoensis Udea. Carbohydrate Polymers, v. 87, no. 3, p. 2046-2051, 2012. https://doi.org/ 10.1016/j.carbpol.2011.10.026 
License information: This is an open-access article distributed under the terms of the Creative Commons Attribution License, which permits unrestricted use, distribution, and reproduction in any medium, provided the original work is properly cited. 